\title{
Combining ability analysis for various yield and quality traits in rice (Oryza sativa L.)
}

\author{
Showkat A. Waza*, H. K. Jaiswal, T. Sravan, Kumari Priyanka, Dilruba A. Bano and Ved \\ P. Rai
}

Department of Genetics and Plant Breeding, Institute of Agricultural Sciences, Banaras Hindu University, Varanasi -221005 (Uttar Pradesh), INDIA

*Corresponding author. E-mail: sahmad777@gmail.com

Received: March 24, 2015; Revised received: September 10, 2015; Accepted: October 27, 2015

\begin{abstract}
An investigation was undertaken to assess the combining ability for yield and quality traits in rice. Three WA cytoplasmic male sterile lines of rice i.e., IR-58025A, IR-68897A and Pusa 6A were crossed with six restorer genotypes i.e., Sanwal Basmati, Pusa Sugandh-2, Pusa Sugandh-3, Pusa Sugandh-5, Pusa 2517-2-51-1 and HURJM-59221 in line $x$ tester design to generate 18 hybrids. Among the female parents, IR-58025A revealed significant desirable value of GCA effect for yield per plant and most of the quality traits. Among the pollen parents, Pusa Sugandh-3 revealed significant desirable value of GCA effect for most of the yield traits. However, Pusa Sugandh-5 revealed significant desirable value of GCA effect for most of the quality traits. Pusa $6 A \times$ Pusa Sugandh-2 evinced the highest significant value of SCA effect for grain yield followed by IR-58025A x Pusa Sugandh-5. However, IR68897A x Pusa 2517-2-51-1 followed by IR-58025A x Sanwal Basmati revealed the significant desirable value of SCA effect for most of the quality traits. For both yield and quality traits, IR-58025A x Pusa Sugandh-5, IR-68897A x HUR-JM-59221 and Pusa 6A x Pusa Sugandh-2 were found to be relatively better performing. Thus, present study aims to develop hybrids performing better for both yield and quality traits.
\end{abstract}

Keywords: GCA, Quality, Rice, SCA, Yield

\section{INTRODUCTION}

About half of the world's population and two third of Indians depend on rice for their survival. There is an urgent need to increase rice production to meet the requirements of ever growing population. In order to narrow the gap between production and demand, increase in productivity is the only option left. Exploitation of heterosis in the form of hybrid rice technology has been contemplated as a potential strategy for enhancing the productivity in rice. The average yield of hybrid rice is at least 15-20 percent more than that of inbred rice and it has been anticipated that hybrid rice technology will play a key role in ensuring food security worldwide in the future decades (FAO, 2014).

The success of hybrid rice breeding depends on the appropriate selection of potential parental lines and subsequent superior crosses. Combining ability analysis is one of the important tools available in selecting the desirable parents and cross combinations for exploitation of heterosis (Sarker et al., 2002 and Rashid et al., 2007). It provides information on the nature and magnitude of gene effects governing various traits. General combining ability (GCA) is attributed to additive gene effects and additive $\mathrm{x}$ additive epistasis, and is theoretically fixable. On the other hand, specific combining ability attributable to non-additive gene action may be due to dominance or epistasis or both and is non-fixable. The presence of non-additive genetic variance is the primary justification for initiating the hybrid programme (Cockerham, 1961 and Pradhan et al., 2006).

Although, number of studies towards combining ability analysis has been carried out for yield and yield traits, but the studies involving both yield and quality traits are lacking, making this an important area of study. Grain quality is second only to yield as the most important breeding objective. In the future, grain quality will be even more important as the very poor portion of our population which depends on rice as the staple food may likely to become prosperous and begin to demand higher quality rice (Babu et al., 2013). Therefore, present investigation was undertaken to assess the combining ability for yield and quality traits in rice to identify the best heterotic combination for both the types of traits.

\section{MATERIALS AND METHODS}

The present investigation was carried out during two seasons viz., kharif-2012 and kharif-2013 at the Agricultural Research Farm, Institute of Agricultural Sciences, Banaras Hindu University, Varanasi (UP). The site of study is situated at $25^{\circ} 18^{\prime} \mathrm{N}$ latitude and $83^{\circ}$ 
03' E longitude, at an elevation of $80.71 \mathrm{~m}$ above mean sea level. The research material in the present study consisted of three WA cytoplasmic male sterile (CMS) lines (IR-58025A, IR-68897A and Pusa 6A) and six genotypes (Sanwal Basmati, Pusa Sugandh-2, Pusa Sugandh-3, Pusa Sugandh-5, Pusa 2517-2-51-1 and HUR-JM-59221) identified as fertility restorers for the CMS lines. All the nine genotypes were obtained from 'All India Coordinated Rice Improvement Project (AICRIP)' at the Department of Genetics and Plant Breeding, Institute of Agricultural Sciences, Banaras Hindu University.

During kharif-2012, all the genotypes were seeded in nursery at 3 dates, 10 days apart and transplanted in crossing blocks at 21 days after sowing. The CMS lines were crossed with the restorers to generate the set of 18 rice hybrids in line $\mathrm{x}$ tester mating design. In kharif-2013, the seed of $F_{1}$ hybrids generated during previous season along with the parental lines were raised at a standard spacing of $20 \times 15 \mathrm{~cm}$ in $5 \mathrm{~m}$ rows in randomized block design with three replications. The recommended package of practices was followed to raise a good crop. Observations were recorded from each replication for both yield and quality traits viz., days to 50 per cent flowering, days to maturity, plant height, number of effective tillers per plant, 100 grain weight, yield per plant, hulling recovery, milling recovery, head rice recovery, kernel length before cooking, kernel breadth before cooking, kernel length after cooking and kernel breadth after cooking. Kernel dimensional analysis was done with the help of electronic grain analyzer. Due to the male sterile nature of the CMS or female lines, their corresponding maintainer lines were used for studying yield and quality traits. The observations for various traits were recorded as per the standard evaluation system of IRRI (1988). Combining ability analysis for various yield and quality traits was accomplished by the method suggested by Kempthorne (1957) through Windostat Version 9.2 from Indostat Services, Hyderabad (India). Character wise estimation of GCA effects of parental lines and SCA effects of cross combinations was carried out. The significance of GCA (General Combining Ability) and SCA (Specific Combining Ability) effects were evaluated by t-test.

\section{RESULTS AND DISCUSSION}

Eighteen $\mathrm{F}_{1}$ hybrids from three CMS lines and six elite quality pollen parents were evaluated to study the combing ability for various yield and quality traits. Analysis of variance for combining ability revealed that all the crosses varied significantly from each other (at $p=0.001$ ) indicating sufficient differences for all the traits (Table 1). The mean squares due to female parents were significant at $5 \%$ probability level ( $\mathrm{p}=$ 0.05 ) for traits viz., days to 50 percent flowering, days to maturity, hulling recovery and kernel breadth before cooking. For characters viz., plant height, effective tillers per plant and kernel length before cooking, the mean squares due to female parents were found to be significant at $1 \%$ probability level $(\mathrm{p}=0.01)$. For the traits 100 grain weight and kernel breadth before cooking, the variances due to male parents were found to be significant at $1 \%$ probability level $(\mathrm{p}=0.01)$. The variances due to male parents were found to be significant at $0.1 \%$ probability level $(\mathrm{p}=0.001)$ for days to $50 \%$ flowering, days to maturity, plant height and kernel length before cooking. Female $\mathrm{x}$ male component of variances were significant at $5 \%$ probability level $(\mathrm{p}=$ 0.05 ) for traits viz., days to 50 percent flowering and number of effective tillers per plant. For rest of the traits studied, female $\mathrm{x}$ male component of variances were significant at $0.1 \%$ probability level $(p=0.001)$, indicating that female parents interacted sufficiently with the male parents. These results are in confirmation with the findings of Akter et al. (2010), and Bagheri and Jelodar (2010) in rice, who also reported that female parents interacted significantly with the male parents.

Combining ability variances in the present study revealed that the magnitude of additive genetic variance $\left(\sigma^{2} \mathrm{~A}\right)$ was higher than dominance genetic variance $\left(\sigma^{2} \mathrm{D}\right)$ for the characters, days to $50 \%$ flowering, days to maturity, plant height, number of effective tillers per plant, 100 grain weight, kernel length before cooking and kernel breadth before cooking, suggesting the preponderance of additive gene action for these traits. However, for the traits yield per plant, hulling recovery, milling recovery, head rice recovery, kernel length after cooking and kernel breadth after cooking, value of $\sigma^{2} \mathrm{~A}$ was observed to be lower than $\sigma^{2} \mathrm{D}$, indicating the predominance of non additive gene action (Table 2 ). The existence of both additive and non additive type of gene action for various yield traits has also been reported by Montazeri et al. (2014). Predominance of non additive gene action for grain yield and its components has been reported by Satyanarayana et al. (2000), Rita and Motiramani (2005), Singh et al. (2005), Venkatesan et al. (2007), Dalvi and Patel (2009), Saidaiah et al. (2010) and Hasan et al. (2013). However, Saravanan et al. (2006), Kumar et al. (2004) and Thakare et al. (2013) while working in the rice reported lower value of $\sigma^{2} \mathrm{~A}$ than $\sigma^{2} \mathrm{D}$ for all the characters studied indicating the predominance of non additive gene action.

The proportional contribution of female parents, male parents and their interaction towards total variance was also estimated (Table 3). Female parents played an important role towards number of effective tillers per plant, indicating predominant maternal influence for this trait. Male parents were more important for days to 50 per cent flowering, days to maturity, plant height, 100 grain weight, kernel length before cooking and kernel breadth before cooking, revealing the predominant paternal influence for these traits. The contribution of maternal and paternal interaction (female $\mathrm{x}$ 
male) was observed to be highest in proportion for the traits, yield per plant, hulling recovery, milling recovery, head rice recovery, kernel length after cooking and kernel breadth after cooking, indicating that these characters are influenced by non additive gene action. High contribution of maternal and paternal interaction in rice for the traits viz., days to $50 \%$ flowering, plant height, productive tillers per plant, 1000 grain weight and grain yield per plant have been reported by Raju et al. (2014). However, low contribution of maternal and paternal interaction towards the total variance was reported by Sarker et al. (2002), Rashid et al. (2007) and Montazeri et al. (2014) for various traits studied.

Both GCA and SCA effects were estimated for yield as well as quality traits. The estimates of combining ability effects aid in selecting desirable parents and crosses, as well as the suitable breeding procedures for further improvement of various yield and quality traits in rice (Sarker et al., 2002 and Rashid et al., 2007). Thus to exploit maximum heterosis in hybrid rice breeding programmes, we must know the combining ability effects for various traits.

Combining ability effects for yield and yield traits: Both general and specific combining ability effects for yield and yield attributes are indicated in Tables 4 and 5 . For the traits, days to 50 per cent flowering, days to maturity and plant height, negative combining ability effects are generally considered to be desirable. However, for number of effective tillers per plant, 100 grain weight and yield per plant, the positive estimates are usually preferable.

Significant negative GCA effect (at $p=0.001$ ) for days to 50 per cent flowering among CMS lines was exhibited by IR-68897A. Within pollen parents, the highest significant desirable GCA effect was revealed by Pusa Sugandh-3 followed by Pusa 2517-2-51-1 and Pusa Sugandh-5. None of the 18 hybrids recorded significant negative value of SCA effect. Significant negative GCA and SCA effects for days to 50 per cent flowering in rice have also reported by Tiwari et al. (2011) and Latha et al. (2013). Bagheri and Jelodar (2010) observed that IR-58025A exhibited undesirable GCA effect, but most of its crosses revealed desirable SCA effects for days to $50 \%$ flowering.

The significant negative estimate of GCA effect for days to maturity among the CMS lines was recorded by IR-68897A, whereas amongst the male parents, the highest significant negative value of GCA effect was observed in Pusa Sugandh-3 followed by Pusa Sugnadh-5 and Pusa 2517-2-51-1. Hybrid, IR-68897A x Pusa Sugandh-5 showed highest significant negative SCA effect followed by IR-58025A x Sanwal Basmati and IR-68897A x Pusa 2517-2-51-1. Koli et al. (2013) observed Pusa Sugandh-5 as a poor general combiner for days to maturity, but recorded average specific combining ability for all its crosses studied. The cross, Pusa 2517-2-51-1 x Pusa Basmati-1 was a good specific combiner for days to maturity (Salgotra et al.,
2009).

Among the female parents, IR-68897A recorded significant negative GCA effect for plant height. Among the male parents, Pusa Sugandh-2 recorded significantly highest negative GCA effect followed by Pusa Sugandh-5 and Pusa Sugandh-3. Hybrid, IR-58025A x HUR-JM-59221 exhibited highest significant desirable value of SCA effect followed by Pusa 6A x Pusa Sugandh-5. Bagheri and Jelodar (2010) reported that IR58025A exhibited undesirable GCA effects as well as undesirable SCA effects in most of its cross combinations for plant height in rice. Salgotra et al. (2009) reported Pusa 2517-2-51-1 and Sanwal Basmati as good general combiners, and cross Pusa 2517-2-51-1 x Pusa Basmati-1 as good specific combination for plant height.

The significant positive value of GCA effect for effective tillers per plant amongst the female and male parents was observed in IR-68897A and Sanwal Basmati, respectively. The cross IR-68897A x Pusa Sugandh-3 recorded significant desirable estimate of SCA effect. Hasan et al. (2013) reported IR-58025A as a good general combiner for number of tillers per plant. Pusa 2517-2-51-1 was also reported to be good combiner for effective tillers per plant by Salgotra et al. (2009).

The significant desirable value of GCA effect for 100 grain weight was not observed in any of the female parents. However, among the male parents, the maximum significant positive value of GCA effect was observed for Pusa 2517-2-51-1 followed by Pusa Sugandh-3 and Pusa Sugandh-2. Highest significant desirable value of SCA effect for 100 grain weight was recorded by IR-68897A x Sanwal Basmati followed by IR-68897A x HUR-JM-59221 and Pusa 6A x Pusa 2517-2-51-1. The cross, Pusa 2517-2-51-1 x Pusa Basmati-1 was observed to be good specific combination for 1000 grain weight by Salgotra et al. (2009).

Amongst the female and male parents, significant positive value of GCA effect for grain yield per plant was observed for IR-58025A and Pusa Sugandh-3, respectively. The cross combination, Pusa 6A x Pusa Sugandh-2 revealed highest significant positive value of SCA effect, followed by IR-58025A x Pusa Sugandh-5 and Pusa 6A x Pusa 2517-2-51-1. CMS line IR$68897 \mathrm{~A}$ was observed to be the good general combiner for grain yield per plant by Thakare et al. (2013). Bagheri and Jelodar (2010) observed that IR-58025A exhibits undesirable GCA effect for grain yield, while most of its cross combinations revealed desirable SCA effects for the trait. Salgotra et al. (2009) reported that Pusa 2517-2-51-1 was the best general combiner followed by Sanwal Basmati for yield per plant, while Pusa 2517-2-51-1 x Pusa Basmati-1 was observed to be good specific combination for the trait in their study.

Combining ability effects for various quality traits: Grain quality in rice is very difficult to define with precision as preferences for quality vary from region to 
Table 3. Proportional (per cent) contribution of female parents, male parents and their interaction to total variance.

\begin{tabular}{llccc}
\hline S. No. & Characters & Female parent & Male parent & $\begin{array}{c}\text { Female } \mathbf{x} \\
\text { male } \\
\text { interaction }\end{array}$ \\
\hline 1 & Days to 50 per cent flowering & 12.12 & 9.33 \\
2 & Days to maturity & 14.03 & 78.55 & 10.11 \\
3 & Plant height & 17.80 & 75.86 & 10.23 \\
4 & Number of effective tillers per plant & 50.98 & 71.97 & 32.52 \\
5 & 100 grain weight & 0.76 & 16.49 & 24.42 \\
6 & Yield per plant & 12.61 & 74.82 & 63.45 \\
7 & Hulling recovery & 40.50 & 23.94 & 45.01 \\
8 & Milling recovery & 2.69 & 14.48 & 80.79 \\
9 & Head rice recovery & 28.22 & 16.53 & 49.34 \\
10 & Kernel length before cooking & 10.26 & 22.45 & 4.48 \\
11 & Kernel breadth before cooking & 19.64 & 85.25 & 61.14 \\
12 & Kernel length after cooking & 25.73 & 25.54 & 19.22 \\
13 & Kernel breadth after cooking & 7.25 & 30.05 & 48.73 \\
\hline
\end{tabular}

Table 4. Estimates of general combining ability (GCA) effects of parental lines for yield and yield traits.

\begin{tabular}{|c|c|c|c|c|c|c|}
\hline Genotypes & $\begin{array}{c}\text { Days to } 50 \% \\
\text { flowering }\end{array}$ & $\begin{array}{c}\text { Days to } \\
\text { maturity }\end{array}$ & $\begin{array}{l}\text { Plant } \\
\text { height }\end{array}$ & $\begin{array}{l}\text { Effective till- } \\
\text { ers per plant }\end{array}$ & $\begin{array}{l}100 \text { grain } \\
\text { weight }\end{array}$ & $\begin{array}{c}\text { Yield per } \\
\text { plant }\end{array}$ \\
\hline \multicolumn{7}{|l|}{ Female parents } \\
\hline IR-58025A & $1.91 * * *$ & $1.93 * * *$ & $1.63 * *$ & $-0.90 * *$ & -0.01 & $1.30 * * *$ \\
\hline IR-68897A & $-2.37 * * *$ & $-2.69 * * *$ & $-4.93 * * *$ & $1.37 * * *$ & 0.00 & $-0.74 *$ \\
\hline Pusa 6A & 0.46 & $0.76^{*}$ & $3.30 * * *$ & -0.47 & 0.01 & -0.55 \\
\hline S.E. $( \pm)$ & 0.49 & 0.33 & 0.57 & 0.27 & 0.01 & 0.35 \\
\hline \multicolumn{7}{|l|}{ Male parents } \\
\hline Sanwal Basmati & $2.63^{* * *}$ & $2.76^{* * *}$ & $14.18^{* * *}$ & $0.82 *$ & $-0.24 * * *$ & 0.21 \\
\hline Pusa Sugandh-2 & $-1.93 * *$ & $-1.24 *$ & $-6.23 * * *$ & 0.19 & $0.04 * *$ & -0.94 \\
\hline Pusa Sugandh-3 & $-3.70 * * *$ & $-4.02 * * *$ & $-3.87 * * *$ & 0.00 & $0.08 * * *$ & $2.00 * * *$ \\
\hline Pusa Sugandh-5 & $-2.59 * * *$ & $-3.24 * * *$ & $-4.81 * * *$ & 0.22 & 0.01 & $-2.05 * * *$ \\
\hline Pusa $2517-2-51-1$ & $-3.37 * * *$ & $-3.13 * * *$ & $-3.37 * * *$ & -0.17 & $0.12 * * *$ & 0.08 \\
\hline HUR-JM-59221 & $8.96 * * *$ & $8.87 * * *$ & $4.10^{* * *}$ & $-1.05 * *$ & 0.00 & 0.71 \\
\hline S.E. $( \pm)$ & 0.69 & 0.47 & 0.80 & 0.38 & 0.01 & 0.50 \\
\hline
\end{tabular}

region. The concept of quality varies according to the preparations for which grains are to be used. Although some of the quality characteristics desired by grower, miller and consumer may be the same, yet each may place different emphasis on various quality characteristics. The miller's basis of quality is dependent upon total recovery and the proportion of head and broken rice on milling. Consumers base their concept of quality on the grain appearance, size and shape of the grain, the behaviour upon cooking, the taste, tenderness and flavour of cooked rice. The quality in rice may, therefore, be considered from viewpoint of milling quality, grain size, shape and appearance, and cooking characteristics. In general, for the quality traits viz., hulling recovery, milling recovery, head rice recovery, kernel length before cooking and kernel length after cooking, positive combining ability effects are considered to be desirable. However, for kernel breadth before and after cooking, negative estimates are usually preferable. In the present study, both general and specific combining ability effects were estimated for various quality attributes (Table 6 and 7).

For hulling recovery, significant positive value of
GCA effect among the female and male parents was recorded by Pusa 6A and Pusa Sugandh-5, respectively. The highest significant positive value of SCA effect for hulling recovery was recorded by IR-68897A $x$ Pusa 2517-2-51-1 followed by Pusa 6A x Pusa Sugandh-5 and IR-68897A x Sanwal Basmati. Thakare et al. (2013) reported both positive and negative SCA effects for hulling recovery in various crosses involving IR-68897A.

In case of milling recovery, none of the CMS parents was observed to reveal significant positive value of GCA effect. However, among the pollen parents, only one genotype (Sanwal Basmati) recorded significant positive GCA value for the trait. Highest significant positive value of SCA effect within the cross combinations was revealed by IR-68897A x Pusa 2517-2-51-1 followed by Pusa 6A x Pusa Sugandh-3. Thakare et al. (2013) reported both positive and negative significant GCA effects for milling recovery for different CMS lines as well as male lines studied. IR-68897A was reported to show significant positive GCA effect for milling recovery by these workers.

Amongst the CMS lines, significant positive value of 
Table 5. Estimates of specific combining ability (SCA) effects for yield and yield traits.

\begin{tabular}{|c|c|c|c|c|c|c|}
\hline Cross combinations & $\begin{array}{c}\text { Days to } \\
50 \% \\
\text { flowering }\end{array}$ & $\begin{array}{l}\text { Days to } \\
\text { maturity }\end{array}$ & $\begin{array}{l}\text { Plant } \\
\text { height }\end{array}$ & $\begin{array}{c}\text { Effective } \\
\text { tillers per } \\
\text { plant }\end{array}$ & $\begin{array}{l}100 \text { grain } \\
\text { weight }\end{array}$ & $\begin{array}{c}\text { Yield per } \\
\text { plant }\end{array}$ \\
\hline IR-58025A x Sanwal Basmati & -1.24 & $-2.26^{* *}$ & -1.62 & 0.09 & -0.04 & -1.38 \\
\hline IR-58025A x Pusa Sugandh-2 & -2.02 & -1.26 & 2.46 & 0.54 & $0.05 *$ & -0.91 \\
\hline IR-58025A x Pusa Sugandh-3 & 1.09 & 0.19 & -0.58 & -0.90 & -0.02 & $-1.90 *$ \\
\hline IR-58025A x Pusa Sugandh-5 & 0.65 & 0.41 & 2.03 & -0.50 & 0.05 & $3.19 * * *$ \\
\hline IR-58025A x Pusa 2517-2-51-1 & -0.24 & 0.63 & $4.26 * *$ & 0.42 & 0.02 & 0.45 \\
\hline IR-58025A x HUR-JM-59221 & 1.76 & $2.30 * *$ & $-6.55 * * *$ & 0.34 & $-0.06^{*}$ & 0.55 \\
\hline IR-68897A x Sanwal Basmati & $2.70 *$ & $3.69 * * *$ & 2.25 & -0.20 & $0.14 * * *$ & $2.13 *$ \\
\hline IR-68897A x Pusa Sugandh-2 & $2.59 *$ & $1.69 *$ & -2.28 & 0.18 & $-0.06^{*}$ & $-2.34 *$ \\
\hline IR-68897A x Pusa Sugandh-3 & 0.04 & -0.20 & -0.17 & $2.06^{* *}$ & $-0.05^{*}$ & 1.71 \\
\hline IR-68897A x Pusa Sugandh-5 & -2.41 & $-2.31 * *$ & 0.94 & -0.41 & -0.03 & -0.42 \\
\hline IR-68897A x Pusa 2517-2-51-1 & -1.30 & $-2.09^{*}$ & -2.50 & -1.22 & $-0.10 * * *$ & $-3.11 * *$ \\
\hline IR-68897A x HUR-JM-59221 & -1.63 & -0.76 & 1.76 & -0.41 & $0.09 * * *$ & $2.03 *$ \\
\hline Pusa 6A x Sanwal Basmati & -1.46 & -1.43 & -0.62 & 0.11 & $-0.10 * * *$ & -0.74 \\
\hline Pusa 6A x Pusa Sugandh-2 & -0.57 & -0.43 & -0.18 & -0.73 & 0.01 & $3.26 * * *$ \\
\hline Pusa 6A x Pusa Sugandh-3 & -1.13 & 0.02 & 0.76 & -1.16 & $0.07 * *$ & 0.19 \\
\hline Pusa 6A x Pusa Sugandh-5 & 1.76 & $1.91 *$ & $-2.97 *$ & 0.91 & -0.02 & $-2.78 * *$ \\
\hline Pusa 6A x Pusa 2517-2-51-1 & 1.54 & 1.46 & -1.76 & 0.80 & $0.08 * *$ & $2.65 * *$ \\
\hline Pusa 6A x HUR-JM-59221 & -0.13 & -1.54 & $4.78 * *$ & 0.07 & -0.03 & $-2.58 * *$ \\
\hline S.E. $( \pm)$ & 1.20 & 0.82 & 1.39 & 0.67 & 0.02 & 0.86 \\
\hline
\end{tabular}

$*, * *, * * *=$ Significant at $0.05,0.01$ and 0.001 levels, respectively.

Table 6. Estimates of general combining ability (GCA) effects of parental lines for various quality traits.

\begin{tabular}{llllllll}
\hline Genotypes & HR & MR & HRR & KLBC & KBBC & KLAC & KBAC \\
\hline Female parents & & & & & & & \\
\hline IR-58025A & $-1.00^{* * *}$ & -0.24 & $3.91^{* * *}$ & $0.13^{* * *}$ & $-0.03^{* * *}$ & $0.13^{* * *}$ & $-0.08^{* * *}$ \\
IR-68897A & -0.24 & -0.07 & -0.11 & $-0.14^{* * *}$ & $0.07^{* * *}$ & $-0.54^{* * *}$ & $0.06^{* * *}$ \\
Pusa 6A & $1.24 * * *$ & 0.31 & $-3.80^{* * *}$ & 0.01 & $-0.04^{* * *}$ & $0.41^{* * *}$ & $0.02^{* *}$ \\
S.E. ( \pm ) & 0.23 & 0.30 & 0.30 & 0.01 & 0.01 & 0.01 & 0.01 \\
\hline Male parents & & & & & & & $-0.44^{* * *}$ \\
\hline Sanwal Basmati & 0.25 & $1.09^{*}$ & $4.76^{* * *}$ & $-0.42^{* * *}$ & 0.01 & $0.08^{* * *}$ \\
Pusa Sugandh-2 & -0.51 & -0.10 & $-0.86^{*}$ & $0.28^{* * *}$ & 0.01 & $-0.28^{* * *}$ & $0.06^{* * *}$ \\
Pusa Sugandh-3 & -0.16 & 0.35 & $-2.52^{* * *}$ & $0.20^{* * *}$ & $-0.04^{* * *}$ & $0.72^{* * *}$ & $-0.08^{* * *}$ \\
Pusa Sugandh-5 & $0.74^{*}$ & -0.40 & $-3.83^{* * *}$ & $0.08^{* * *}$ & $-0.16^{* * *}$ & $0.32^{* * *}$ & $-0.18^{* * *}$ \\
Pusa 2517-2-51-1 & $-0.84^{*}$ & -0.46 & $1.22^{* *}$ & $0.31^{* * *}$ & $0.04 * * *$ & $-0.06^{* * *}$ & $-0.06^{* * *}$ \\
HUR-JM-59221 & 0.51 & -0.48 & $1.23^{* *}$ & $-0.45^{* * *}$ & $0.14^{* * *}$ & $-0.26^{* * *}$ & $0.18^{* * *}$ \\
S.E. ( \pm ) & 0.33 & 0.42 & 0.42 & 0.01 & 0.01 & 0.01 & 0.01 \\
\hline
\end{tabular}

$\mathrm{HR}=$ Hulling recovery $(\%), \mathrm{MR}=$ Milling recovery $(\%), \mathrm{HRR}=\mathrm{Head}$ rice recovery $(\%), \mathrm{KLBC}=$ Kernel length before cooking $(\mathrm{mm}), \mathrm{KBBC}=$ Kernel breadth before cooking $(\mathrm{mm}), \mathrm{KLAC}=$ Kernel length after cooking $(\mathrm{mm})$ and KBAC $=$ Kernel breadth after cooking $(\mathrm{mm})(*, * *, * * *=$ Significant at $0.05,0.01$ and 0.001 levels, respectively).

GCA effect for head rice recovery was observed for IR $-58025 \mathrm{~A}$, while among the pollen parents, highest significant desirable value of GCA effect was recorded for Sanwal Basmati followed by HUR-JM-59221 and Pusa 2517-2-51-1. Highest significant positive value of SCA effect for head rice recovery was revealed by IR68897A x Pusa 2517-2-51-1, followed by Pusa 6A x Pusa Sugandh-2 and IR-58025A x Pusa Sugandh-5. Thakare et al. (2013) reported IR-68897A to exhibit significant positive GCA effect for head rice recovery. Both positive and negative SCA effects in various cross combinations of IR-68897A were also reported by these workers for head rice recovery.
Among the female parents, IR-58025A recorded significant positive estimate of GCA effect for kernel length before cooking. Significant positive GCA effect among the male parents was observed in Pusa 2517-251-1, followed by Pusa Sugandh-2 and Pusa Sugandh3. Amongst the hybrids, IR-68897A x Pusa Sugandh-3 evinced highest significant positive SCA effect, followed by Pusa 6A x Pusa Sugandh-2 and IR-58025A x Pusa 2517-2-51-1. Priyanka et al. (2014) reported IR$58025 \mathrm{~A}$ as good general combiner and IR-68897A as poor general combiner for kernel length before cooking. This supports the findings of the present study. Thakare et al. (2013) reported both desirable and unde- 
Table 7. Estimates of specific combining ability (SCA) effects for various quality traits.

\begin{tabular}{|c|c|c|c|c|c|c|c|}
\hline Cross combinations & HR & MR & HRR & KLBC & KBBC & KLAC & KBAC \\
\hline $\begin{array}{l}\text { IR-58025A x Sanwal } \\
\text { Basmati }\end{array}$ & -0.07 & -0.32 & 1.22 & $0.08 * *$ & $-0.12 * * *$ & $0.58 * * *$ & $-0.13 * * *$ \\
\hline $\begin{array}{l}\text { IR-58025A x Pusa } \\
\text { Sugandh-2 }\end{array}$ & -0.21 & -1.37 & $-5.22 * * *$ & $-0.06 *$ & $0.07 * * *$ & $0.38 * * *$ & $0.27 * * *$ \\
\hline $\begin{array}{l}\text { IR-58025A x Pusa } \\
\text { Sugandh-3 }\end{array}$ & 0.82 & 0.64 & $1.56^{*}$ & $-0.10 * * *$ & 0.01 & $-0.42 * * *$ & 0.02 \\
\hline $\begin{array}{l}\text { IR-58025A x Pusa } \\
\text { Sugandh-5 }\end{array}$ & 0.64 & 1.03 & $4.49 * * *$ & -0.02 & -0.01 & $-0.23 * * *$ & $-0.36 * * *$ \\
\hline $\begin{array}{l}\text { IR-58025A x Pusa } \\
2517-2-51-1\end{array}$ & -0.76 & -0.78 & $-3.83 * * *$ & $0.08 * *$ & -0.01 & $0.24 * * *$ & $0.26^{* * *}$ \\
\hline $\begin{array}{l}\text { IR-58025A x HUR-JM- } \\
59221\end{array}$ & -0.43 & 0.81 & $1.77 *$ & 0.03 & $0.06 * * *$ & $-0.55 * * *$ & $-0.07 * * *$ \\
\hline $\begin{array}{l}\text { IR-68897A x Sanwal } \\
\text { Basmati }\end{array}$ & $1.17 *$ & -0.20 & $-1.94 *$ & $-0.09 * * *$ & $0.08 * * *$ & $-0.39 * * *$ & $0.06^{* * *}$ \\
\hline $\begin{array}{l}\text { IR-68897A x Pusa } \\
\text { Sugandh-2 }\end{array}$ & 0.94 & 0.42 & $-1.89^{*}$ & -0.04 & $-0.07 * * *$ & 0.03 & $-0.06 * * *$ \\
\hline $\begin{array}{l}\text { IR-68897A x Pusa } \\
\text { Sugandh-3 }\end{array}$ & $-1.39 *$ & $-2.16^{* *}$ & $-3.65 * * *$ & $0.15 * * *$ & -0.01 & $-0.99 * * *$ & $-0.15 * * *$ \\
\hline $\begin{array}{l}\text { IR-68897A x Pusa } \\
\text { Sugandh-5 }\end{array}$ & $-2.05 * * *$ & -1.41 & $-4.56 * * *$ & -0.04 & -0.02 & $0.35 * * *$ & $0.23 * * *$ \\
\hline $\begin{array}{l}\text { IR-68897A x Pusa } \\
2517-2-51-1\end{array}$ & $1.45^{*}$ & $2.62 * *$ & $9.45 * * *$ & $-0.05 *$ & 0.01 & $0.18 * * *$ & $-0.19 * * *$ \\
\hline $\begin{array}{l}\text { IR-68897A x HUR-JM- } \\
59221\end{array}$ & -0.12 & 0.73 & $2.59 * *$ & $0.06 *$ & 0.02 & $0.82 * * *$ & $0.12 * * *$ \\
\hline $\begin{array}{l}\text { Pusa 6A x Sanwal } \\
\text { Basmati }\end{array}$ & -1.10 & 0.53 & 0.72 & 0.01 & $0.04 * *$ & $-0.19 * * *$ & $0.07 * * *$ \\
\hline $\begin{array}{l}\text { Pusa 6A x Pusa } \\
\text { Sugandh-2 }\end{array}$ & -0.73 & 0.96 & $7.10 * * *$ & $0.10 * * *$ & 0.00 & $-0.41 * * *$ & $-0.21 * * *$ \\
\hline $\begin{array}{l}\text { Pusa 6A x Pusa } \\
\text { Sugandh-3 }\end{array}$ & 0.56 & $1.51 *$ & $2.09 * *$ & $-0.05 *$ & 0.00 & $1.41 * * *$ & $0.13 * * *$ \\
\hline $\begin{array}{l}\text { Pusa } 6 \text { A x Pusa } \\
\text { Sugandh-5 }\end{array}$ & $1.41 *$ & 0.38 & 0.08 & $0.06^{*}$ & $0.03 *$ & $-0.12 * * *$ & $0.13 * * *$ \\
\hline $\begin{array}{l}\text { Pusa 6A x Pusa } \\
2517-2-51-1\end{array}$ & -0.69 & $-1.84 *$ & $-5.61 * * *$ & -0.03 & 0.00 & $-0.41 * * *$ & $-0.07 * * *$ \\
\hline $\begin{array}{l}\text { Pusa 6A x HUR-JM- } \\
59221\end{array}$ & 0.55 & $-1.54 *$ & $-4.37 * * *$ & $-0.09 * * *$ & $-0.08 * * *$ & $-0.27 * * *$ & $-0.05 * *$ \\
\hline S.E. $( \pm)$ & 0.56 & 0.73 & 0.73 & 0.02 & 0.01 & 0.03 & 0.01 \\
\hline
\end{tabular}

$\mathrm{HR}=$ Hulling recovery $(\%), \mathrm{MR}=$ Milling recovery $(\%), \mathrm{HRR}=$ Head rice recovery $(\%), \mathrm{KLBC}=$ Kernel length before cooking $(\mathrm{mm}), \mathrm{KBBC}=$ Kernel breadth before cooking $(\mathrm{mm}), \mathrm{KLAC}=$ Kernel length after cooking $(\mathrm{mm})$ and $\mathrm{KBAC}=$ Kernel breadth after cooking $(\mathrm{mm})(*, * *, * *=$ Significant at $0.05,0.01$ and 0.001 levels, respectively).

sirable GCA effects for kernel length in different CMS as well as male lines studied. IR-68897A was reported to show significant negative GCA effect for kernel length by these researchers. Both desirable and undesirable SCA effects for kernel length in various cross combinations were reported by Thakare et al. (2013) in their studies.

For kernel breadth before cooking, the CMS lines Pusa 6A and IR-58025A recorded significant negative GCA effects. Among the pollen parents, significant desirable values of GCA effect for kernel breadth was revealed by Pusa Sugandh-5 and Pusa Sugandh-3. Hybrid, IR58025A x Sanwal Basmati evinced highest significant negative value of SCA effect for the trait. Significant desirable values of SCA effect were also revealed by
Pusa 6A x HUR-JM-59221 and IR-68897A x Pusa Sugandh-2. Priyanka et al. (2014) reported IR-58025A and Pusa 6A as poor general combiners, while IR68897A as good general combiner for kernel breadth before cooking which is in accordance with the present findings.

Among the female parents, significant positive estimate of GCA effect for kernel length after cooking was recorded by Pusa 6A and IR-58025A. Significant desirable GCA effect for kernel length after cooking among the male parents was observed in Pusa Sugandh -3 and Pusa Sugandh-5. Amongst the hybrids, Pusa 6A $\mathrm{x}$ Pusa Sugandh-3 showed highest significant positive SCA effect followed by IR-68897A x HUR-JM-59221 and IR-58025A x Sanwal Basmati. 
In case of kernel breadth after cooking, the CMS line IR-58025A was observed to show significant negative GCA effect. Among the pollen parents, significant desirable value of GCA effect for the trait was recorded by Pusa Sugandh-5, Pusa Sugandh-3 and Pusa 2517-2-51-1. Cross combination, IR-58025A x Pusa Sugandh-5 recorded highest negative significant value of SCA effect followed by Pusa 6A x Pusa Sugandh-2 and IR-68897A x Pusa 2517-2-51-1 for kernel breadth after cooking.

To summarise, none of the parents showed significant desirable GCA effects simultaneously in desired direction for all the traits studied. Similar results have been reported by Tiwari et al. (2011) and Latha et al. (2013). Moreover, none of the crosses exhibited significant and desirable SCA effects for all the characters, indi-cating that no specific combination was desirable for all traits. These results are in complete agreement with ear-lier findings of Tiwari et al. (2011), Ghara et al. (2012), and Sanghera and Hussain (2012). Among the female parents, IR-58025A revealed significant desirable value of GCA effect for yield per plant and most of the quality traits. Among the pollen parents, Pusa Sugandh-3 revealed significant desirable value of GCA effect for most of the yield traits. However, Pusa Sugandh-5 followed by Pusa Sugandh-3 revealed the significant desirable value of GCA effect for most of the quality traits. For cross combinations, Pusa 6A x Pusa Sugandh-2 evinced the highest significant value of SCA effect for grain yield followed by IR-58025A x Pusa Sugandh-5. However, IR-68897A x Pusa 2517-2-51-1 followed by IR-58025A x Sanwal Basmati revealed the significant desirable value of SCA effect for most of the quality traits. For both yield and quality traits, IR-58025A x Pusa Sugandh-5, IR-68897A x HUR-JM-59221 and Pusa 6A x Pusa Sugandh-2 were found to be relatively better performing. It was observed that best cross combinations are not always found between high $\mathrm{x}$ high general combiners, but may also occur in other types of parental combinations. Chakraborty et al. (2009) and Tiwari et al. (2011) have reported that in order to obtain heterotic hybrids, it is better to select at least one parent possessing high GCA and other with low, average or high GCA. Hariprasanna et al. (2006) have reported that high $\mathrm{x}$ high GCA combination resulted in significant negative SCA for some traits in rice, which confirm the present findings.

\section{Conclusion}

The cross combination, Pusa 6A x Pusa Sugandh-2 evinced highest significant value of SCA effect for grain yield. However, IR-68897A x Pusa 2517-2-51-1 revealed significant desirable value of SCA effect for most of the quality traits. For both yield and quality traits, IR-58025A x Pusa Sugandh-5, IR-68897A x HUR-JM-59221 and Pusa 6A x Pusa Sugandh-2 were found to be better performing. The hybrids recording positive and significant SCA effects in the present study need to be further tested in observational/multilocation trials to exploit their heterotic potential at commercial level. Moreover, the cross combinations which show non-significant SCA effects but originated from parental lines having high GCA effects can be used for recombination breeding with an easy selection of desirable segregants, particularly for developing better performing pure lines.

\section{REFERENCES}

Akter, A., Hasan, M. J., Begum, H., Kulsum, M. U. and Hossain, M. K. (2010). Combining ability analysis in rice (Oryza sativa L.). Bangladesh Journal of Plant Breeding and Genetics, 23 (2): 7-13.

Bagheri, N. and Jelodar, N. B. (2010). Heterosis and combining ability analysis for yield and related-yield traits in hybrid rice. International Journal of Biology, 2 (2): 222 -231 .

Babu, V. R., Shreya, K., Dangi, K. S., Usharani, G. and Nagesh, P. (2013). Evaluation of Popular Rice (Oryza sativa L.). Hybrids for Quantitative, Qualitative and Nutritional Aspects. International Journal of Scientific and Research Publications, 3 (1): 1-8.

Chakraborty, R., Chakraborty, S., Dutta, B.K. and Paul, S.B. (2009). Combining ability analysis for yield and yield components in bold grained rice (Oryza sativa L.) of Assam. Acta Agronomica, 58 (1): 9-13.

Cockerham, C.C. (1961). Implication of genetic variances in hybrid breeding programme. Crop Science, 8: 720-722.

Dalvi, V. V. and Patel, D. V. (2009). Combining ability anlysis for yield in hybrid rice. Oryza, 46 (2): 97-102.

FAO. (2014). A regional strategy for sustainable hybrid rice development in Asia. Food and Agriculture Organization of the United Nations, Regional office for Asia and the Pacific, Bangkok, p.6.

Ghara, A.G., Nematzadeh, G., Bagheri, N., Ebrahimi, A. and Oladi, M. (2012). Evaluation of general and specific combining ability in parental lines of hybrid rice, International Journal of Agriculture: Research and Review, 2 (4): 455-460.

Hariprasanna, K., Zaman, F.U., Singh, A.K. and Tomar S. M.S. (2006). Analysis of combining ability status among parents and hybrids in rice (Oryza sativa L.). The Indian Journal of Genetics and Plant Breeding, 66 (1): 28-30.

Hasan, M. J., Kulsum, U. K., Lipi, L. F. and Shamsuddin, A. K. M. (2013). Combining ability studies for developing new rice hybrids in Bangladesh. Bangladesh Journal of Botany, 42 (2): 215-222.

IRRI. 1988. Standard evaluation system for rice. International Rice Research Institute, Los Banos, Manila, Philippines. $35 \mathrm{p}$.

Kempthorne, O. (1957). An Introduction to Genetic Statistics. John Wiley and Sons Inc. New York.

Koli, N.R., Prakash, C., Punia, S.S. and Kumhar, B.L. (2013). Line $\mathrm{x}$ tester analysis for grain yield and its contributing traits in aromatic rice (Oryza sativa L.). International Journal of Integrative sciences, Innovation and Technology, 2 (2): 1-4.

Kumar, A., Singh, N.K. and Chaudhary, V.K. (2004). Line x tester analysis for grain yield and related characters in 
rice. Madras Agricultural Journal, 91 (4-6): 211-214.

Latha, S., Sharma, D. and Sanghera, G. S. (2013). Combining ability and heterosis for grain yield and its component trait in rice (Oryza sativa L.). Notulae Scientia Biologicae, 5 (1): 90-97.

Montazeri, Z., Jelodar, N. B. and Bagheri, N. (2014). Genetic dissection of some important agronomic traits in rice using line $\mathrm{x}$ tester method. International Journal of Advanced Biological and Biomedical Research, 2 (1): 181-191.

Pradhan, S. K., Bose, L. K. and Mani, S. C. (2006). Basmati type restorers and maintainers for two cytosterile lines of rice (Oryza sativa L.). Indian Journal of Genetics and Plant Breeding, 66 (4): 335-336.

Priyanka, K., Jaiswal, H. K. and Waza, S. A. (2014). Combining ability and heterosis for yield, its component traits and some grain quality parameters in rice (Oryza sativa L.). Journal of Applied and Natural Science, 6 (2): 495-506.

Raju, C. D., Kumar, S. S., Raju, C. S. and Srijan, A. (2014). Combining ability studies in the selected parents and hybrids in rice (Oryza sativa L.). International Journal of Pure and Applied Bioscience, 2 (4): 271-279.

Rashid, M., Cheema, A. A., and Ashraf, M. (2007). Line x tester analysis in basmati rice. Pakistan Journal of Botany, 39(6): 2035-2042.

Rita, B. and Motiramani, N. K. (2005). Study on gene action and combining ability in rice. Oryza, 42 (2): 153-155.

Saidaiah, P. S., Kumar, S. and Ramesha, M. S. (2010). Combining ability studies for development of new hybrids in rice over environments. Journal of Agricultural Sciences, 2 (2): 225-233.

Salgotra, R. K., Gupta, B. B. and Singh, P. (2009). Combin- ing ability studies for yield and yield components in basmati rice. Oryza, 46 (1): 12-16.

Sanghera, G. S. and Hussain, W. (2012). Heterosis in relation to combining ability per se performance in temperate rice (Oryza sativa L.). Pakistan Journal of Agricultural Research, 25 (3): 12-16.

Saravanan, K., Anbanandan, V. and Kumar, S. P. (2006). Heterosis for yield and yield components in rice (Oryza sativa L.). Crop Research, 31 (2): 242-244.

Sarker, C. K. G., Zaman, F. U. and Singh A. K. (2002). Genetics of fertility restoration of WA based cytoplasmic male sterility system in rice (Oryza sativa L.) using basmati restorer lines. Indian Journal of Genetics and Plant Breeding, 62 (4): 305-308.

Satyanarayana, P. V., Reddy, M. S., Kumar, I. and Madhuri, J. (2000). Combining ability studies on yield and yield components in rice. Oryza, 37(1): 22-25.

Singh, N., Kaur, L., Sodhi, N. S. and Sekhon, K. S. (2005). Physicochemical, cooking and textural properties of milled rice from different Indian rice cultivars. Food Chemistry, 89 (2): 253-259.

Thakare, I. S., Patel, A. L. and Mehta, A. M. (2013). Line x tester analysis using CMS system in rice (Oryza sativa L.). The Bioscan, 8 (4): 1379-1381.

Tiwari, D. K., Pandey, P., Giri, S. P. and Dwivedi, J. L. (2011). Heterosis studies for yield and its components in rice hybrids using CMS system. Asian Journal of Plant Sciences, 10 (1): 29-42.

Venkatesan, M., Anbuselvam, Y., Elangaimannan, R. and Karthikeyan, P. (2007). Combining ability for yield and physiological characters in rice. Crop Improvement, 44 (4): 296-299. 